\title{
Egg quality and yolk lipid composition of laying hens fed diets containing cashew nut meal
}

\author{
Qualidade do ovo e composição lipídica da gema de poedeiras alimentadas com rações \\ contendo farelo da castanha do caju
} Tatiana Fontoura VIDAL ${ }^{1}$, Ana Lúcia Fernandes PEREIRA ${ }^{2 *}$, Virgínia Kelly Gonçalves ABREU²,
Ednardo Rodrigues FREITAS ${ }^{1}$, Manoel Alves SOUSA NETO ${ }^{3}$, Jorge Fernando Fuentes ZAPATA ${ }^{1}$

\begin{abstract}
The objective of this study was to assess the effect of the addition of cashew nuts meal $(0,5,10,15,20$, and $25 \%)$ to laying hen diets on egg quality and yolk composition. The variables studied were: egg weight, specific gravity, Haugh Units, percentages of shell, albumen, and yolk, moisture, total solids, total lipids, fatty acids profile, and yolk cholesterol. The addition of up to $25 \%$ of cashew nuts meal to hen diets did not affect egg quality and freshness, moisture and total solids content. However, an increase in total lipid content and a decrease in yolk pigmentation was observed. Oleic acid level increased in the yolk, whereas palmitic, stearic, and linoleic acid levels decreased. The addition of cashew nuts meal increased the monounsaturated/saturated fatty acid ratio in the yolk and reduced the cholesterol content. Therefore, the use of cashew nuts meal in laying hen diets favorably modifies the fatty acid composition of egg yolk and contributes to a better acceptance of this food by consumers since it also reduces yolk cholesterol levels.
\end{abstract}

Keywords: fatty acid profile; oleic acid; cholesterol.

\section{Resumo}

O objetivo deste trabalho foi avaliar o efeito da inclusão do farelo de castanha de caju $(0,5,10,15,20$ e $25 \%)$ nas rações de poedeiras sobre a qualidade do ovo e a composição lipídica da gema. As variáveis estudadas foram: peso dos ovos, gravidade específica, Unidades Haugh, porcentagem de casca, albúmen e gema, umidade, sólidos totais, lipídios totais, perfil de ácidos graxos e colesterol da gema. A inclusão de até $25 \%$ do farelo da castanha do caju nas rações não afetou as características de qualidade e de frescor do ovo, o teor de umidade e de sólidos totais. No entanto, observou-se um aumento no teor total de lípidios e uma diminuição da pigmentação nas gemas com a inclusão. O nível de ácido oleico aumentou, enquanto que os níveis dos ácidos palmítico, esteárico e linoleico diminuíram. A inclusão de farelo de castanha de caju aumentou a relação dos monoinsaturados/saturados e proporcionou redução no teor de colesterol. Assim, a utilização do farelo da castanha de caju na ração de poedeiras modifica favoravelmente o perfil de ácidos graxos da gema e contribui para uma melhor aceitação deste alimento pelos consumidores, uma vez que também reduz os níveis de colesterol na gema.

Palavras-chave: perfil de ácidos graxos; ácido oleico; colesterol.

\section{Introduction}

Anarcadium occidentale (cashew), a member of the Anacardiaceae family, is a tropical tree indigenous to Brasil and which is now extensively grown in India and east Africa. India is the largest producer of cashew nut, accounting for almost $50 \%$ of world exports. The tree also yields the so-called cashew apple to which the nut is attached. Cashew apple is a very juicy, fibrous, and edible fruit (TREVISAN et al., 2006).

The cashew nut kernels, the edible portion of the nut that contain proteins, fats, and vitamins, are accepted worldwide as a nutritious food product. The cashew nut consists of an outer shell (epicarp), a tightly fitted inner shell (endocarp), and a strongly vesicant cashew nut shell liquid. The kernel is slightly curved back on itself and forms two cotyledons, representing about $20-25 \%$ of whole nut weight. It is wrapped within a thin, reddish-brown membrane called a testa, which is very difficult to remove (KAMATH; RAJINI, 2007; TROX et al., 2010).

According to government data (National Agriculture Research Agency, CONAB, Fortaleza, Ceara, Brazil), Brazil is third largest producer of cashew nut, and Ceara is the leading producer state accounting for almost $57 \%$ of production, which may reach 150000 t/year. About 2 to $5 \%$ of the cashew nut production is unfit for human consumption and have been used as animal feed (FREITAS et al., 2006).

Several studies have investigated alternative ingredients used in animal feeding that can be used reducing production costs while maintaining their performance. Several natural products are being used in layer diets, such as mesquite meal, annatto, leucaena, and garlic (NUNES et al., 2000). In

1 Universidade Federal do Ceará - UFC, CP 12168, CEP 60356-001, Fortaleza, CE, Brasil

2 Universidade Federal do Maranhão - UFMA, Rua Simplício Moreira, 1100, CEP 65900-000, Imperatriz, MA, Brasil, e-mail: anafernandesp@yahoo.com.br

${ }_{3}$ Embrapa Agroindústria Tropical, Rua Doutora Sara Mesquita, 2270, Planalto do Pici, CEP 60511-110, Fortaleza, CE, Brasil

${ }^{*}$ Corresponding author 
northeastern Brazil, currently agribusiness by-products have been used in animal feeding, and industrial processing of cashew generates several by-products, among them the cashew nut meal (CNM).

The CNM may be a partial substitute of corn and soybean meal in poultry diets. This by-product contains about $93.27 \%$ of dry mater and $4654 \mathrm{kcal} / \mathrm{kg}$ metabolizable energy. Moreover, it contains $22.15 \%$ crude protein, $35.97 \%$ ether extract, $6.24 \%$ crude fibre, and $3.09 \%$ of ash (EMBRAPA, 1991). The energy value CNM is greater than that of corn and soybean meal, and its protein, calcium levels, and phosphorus are also higher than those of corn (SILVA et al., 2008).

Soares et al. (2007) evaluated the addition of up 20\% CNM to laying Japanese quail diets. These authors reported that CNM did not adversely affect productivity and egg quality when the addition of CNM to the diet was up to $9 \%$.

As for economic viability, when comparing CNM with corn and soybean meal, Freitas et al. (2006) reported that $\mathrm{CNM}$ addition to broiler diets at levels up to $25 \%$ led to linear reduction in feed cost per kilogram of body weight.

The fatty acid composition of cashew nuts is important with respect to different aspects including nutritional quality since the monounsaturated (MUFA) and polyunsaturated fatty acids (PUFA) are considered more desirable than saturated fatty acids. The MUFAs and PUFAs offer health benefits, especially in relation to blood serum lipid profile (notably the decrease in undesirable low-density cholesterols VLDLs and LDLs) (CHANDRASEKARA; SHAHIDI, 2011).

The cashew nut fatty acid composition is constituted predominantly of miristic $(0.03 \%)$, palmitoleic $(0.54 \%)$, palmitic $(10.70 \%)$, linolenic $(0.32 \%)$, linoleic $(16.88 \%)$, oleic $(61.15 \%)$, margaric $(0.12 \%)$ and estearic acids $(9.33 \%)$ and is therefore considered a source of unsaturated fatty acid (VENKATACHALAM; SATHE, 2006).

The fatty acid profile of the egg yolk is clearly affected by the fatty acid composition of hen diets (AYERZA; COATES, 2001; SZYMOZYK; PISULEWISKI, 2003). Therefore, the addition of CNM to the hen diets can increase the level of unsaturated fatty acids in eggs. Freitas et al. (2000) reported an increase in unsaturated fatty acids and a reduction in cholesterol levels in the abdominal fat of broiler chickens fed diets containing CNM.

Currently, there is no information available on the CNM addition to layer diets. Therefore, this study was conducted to assess the influence of CNM addition to laying hen diets on egg quality and yolk composition.

\section{Materials and methods}

\subsection{Birds and diets}

180 Dekalb Brown laying hens 27 weeks of age were randomly distributed into 6 treatments with 5 replicates of 6 birds each. All experimental diets were isonutrients, based on maize and soybean meal, and formulated according to the recommendations of Embrapa (1991). The treatments consisted of one diet without CNM (control) and five diets containing 5, $10,15,20$, and, $25 \%$ cashew nut meal (CNM).

The ingredient and fatty acid composition of the experimental diets are shown in Tables 1 and 2, respectively.

The experiment was conducted for 84 days consisting of 4 periods of 21 days each. The birds were maintained in cages (1 pair per cage) with water and feed provided ad libitum.

During the entire trial (84 days), eggs were collected daily. The collected eggs were identified and stored $\left(20^{\circ} \mathrm{C}\right)$ once a week, and egg quality analysis was performed on the following day. Three eggs were selected in order to determine quality characteristics measuring specific gravity, Haugh units, and percentage of yolk, albumen, and shell. The color of the yolk was also assessed.

At the end of the third experimental period (day 63), eggs from each replicate were collected and, the yolks separated from the whites. The yolks were then pooled and stored at $-20{ }^{\circ} \mathrm{C}$ until analysis (moisture, total solids, total lipids, lipid profile, and cholesterol).

\subsection{Egg quality characteristics}

Eggs were individually weighed and broken out onto a flat surface where yolks were separated from the whites and then weighed. The shells were carefully washed and cleaned of any adhering albumen. The shells were then dried for 48 hours at room temperature $\left(25^{\circ} \mathrm{C}\right)$ and weighed. Albumen weight was calculated by the difference between total egg weight and shell weight plus yolk. Yolk, albumen, and shell percentages were determined in relation to the egg weight.

Specific gravity was assessed based on the Archimedes principle according to Freitas et al. (2004). The mass of the egg and the water $\left(20^{\circ} \mathrm{C}\right)$ displaced by the egg immersed in a water bowl were weighed. Specific gravity was expressed as the quotient of the egg mass and the mass of the displaced water.

Haugh units were calculated from the measurements of albumen height and egg weight using the following formula: $\mathrm{HU}=100 \times \log \left(\mathrm{H}+7.57-1.7 \times \mathrm{W}^{0.37}\right)$, where $\mathrm{HU}=$ Haugh Units; $\mathrm{H}=$ height of the albumen; and $\mathrm{W}=$ egg weight (SILVERSIDES; BUDGELL, 2004). Yolk color was determined by matching with one of the matching bands of the Roche color fan (AHN et al., 1999).

\subsection{Moisture, total solids, and total lipids of egg yolk}

Moisture content of egg yolks was determined as described by AOAC (ASSOCIATION..., 1990). Total yolk solids were calculated by the difference between 100 and the moisture content. Total lipids were assessed as described in AOAC (ASSOCIATION..., 1990).

\subsection{Fatty acid composition and cholesterol content of egg yolk}

For yolk fatty acid composition, methyl esters were prepared by direct methylation as described by Wang et al. 
Table 1. Composition (\%) of experimental laying hen diets containing different levels of cashew nut meal (CNM).

\begin{tabular}{|c|c|c|c|c|c|c|}
\hline \multirow{2}{*}{ Ingredients } & \multicolumn{6}{|c|}{ Levels of CNM (\%) } \\
\hline & 0 & 5 & 10 & 15 & 20 & 25 \\
\hline Maize & 58.13 & 56.48 & 53.82 & 48.16 & 42.51 & 36.86 \\
\hline Soybean meal & 28.25 & 26.30 & 24.45 & 23.22 & 21.88 & 20.59 \\
\hline CNM & 0.00 & 5.00 & 10.00 & 15.00 & 20.00 & 25.00 \\
\hline Soybean oil & 2.40 & 1.05 & 0.00 & 0.00 & 0.00 & 0.00 \\
\hline Limestone & 8.71 & 8.64 & 8.58 & 8.51 & 8.44 & 8.37 \\
\hline Mineral premix ${ }^{b}$ & 0.05 & 0.05 & 0.05 & 0.05 & 0.05 & 0.05 \\
\hline Methionine & 0.15 & 0.14 & 0.15 & 0.17 & 0.18 & 0.19 \\
\hline Lysine & 0.00 & 0.02 & 0.04 & 0.04 & 0.05 & 0.05 \\
\hline Salt & 0.36 & 0.36 & 0.35 & 0.35 & 0.35 & 0.35 \\
\hline Inert $^{c}$ & 0.00 & 0.00 & 0.58 & 2.50 & 4.52 & 6.50 \\
\hline Crude protein $(\%)$ & 18.00 & 18.00 & 18.00 & 18.00 & 18.00 & 18.00 \\
\hline Calcium (\%) & 3.80 & 3.80 & 3.80 & 3.80 & 3.80 & 3.80 \\
\hline Avaliable phosphorus (\%) & 0.43 & 0.43 & 0.43 & 0.43 & 0.43 & 0.43 \\
\hline Sodium (\%) & 0.18 & 0.18 & 0.18 & 0.18 & 0.18 & 0.18 \\
\hline Lysine total (\%) & 0.93 & 0.93 & 0.93 & 0.93 & 0.93 & 0.93 \\
\hline Methionine tota (\%)l & 0.43 & 0.43 & 0.43 & 0.43 & 0.43 & 0.43 \\
\hline Methionine + cystine total (\%) & 0.72 & 0.72 & 0.72 & 0.72 & 0.72 & 0.72 \\
\hline Threonine (\%) & 0.65 & 0.65 & 0.65 & 0.65 & 0.65 & 0.65 \\
\hline Tryptophan (\%) & 0.20 & 0.20 & 0.20 & 0.20 & 0.20 & 0.20 \\
\hline
\end{tabular}

Table 2. Fatty acid composition (\%) of experimental laying hen diets containing different levels of cashew nut meal (CNM).

\begin{tabular}{|c|c|c|c|c|c|c|}
\hline \multirow{2}{*}{ Fatty acid (\%) } & \multicolumn{6}{|c|}{ Levels of CNM (\%) } \\
\hline & 0 & 5 & 10 & 15 & 20 & 25 \\
\hline Palmitic (C16:0) & $16.64 \pm 0.59$ & $17.60 \pm 0.53$ & $14.96 \pm 0.25$ & $13.71 \pm 0.16$ & $11.49 \pm 0.17$ & $11.01 \pm 0.38$ \\
\hline Stearic (C18:0) & $3.26 \pm 0.34$ & $5.00 \pm 0.24$ & $5.51 \pm 0.28$ & $6.07 \pm 0.31$ & $6.44 \pm 0.25$ & $6.50 \pm 0.25$ \\
\hline Oleic (C18:1) & $23.11 \pm 0.45$ & $33.52 \pm 0.35$ & $42.21 \pm 0.45$ & $48.49 \pm 0.65$ & $51.38 \pm 0.50$ & $51.53 \pm 0.36$ \\
\hline Linoleic (C18:2) & $51.19 \pm 0.79$ & $39.52 \pm 0.47$ & $34.88 \pm 0.46$ & $29.30 \pm 0.62$ & $27.29 \pm 0.75$ & $25.15 \pm 0.28$ \\
\hline Linolenic (C18:3) & $3.73 \pm 0.23$ & $2.20 \pm 0.09$ & $1.55 \pm 0.10$ & $0.98 \pm 0.02$ & $0.91 \pm 0.05$ & $0.75 \pm 0.02$ \\
\hline
\end{tabular}

$\mathrm{n}=5$; Mean \pm standard deviation.

(2000). Chromatographic analyses were performed using a gas chromatograph (VARIAN CP 3380, Walnut Creek, USA) equipped with a flame ionization detector using a fused silica capillary column $(100 \mathrm{~m} \times 0.25 \mathrm{~mm}$ i.d. $)$ and hydrogen as carrier gas at a flow rate of $1.5 \mathrm{~mL} / \mathrm{min}$. The initial temperature of the column was set at $160{ }^{\circ} \mathrm{C}$, and it was increased to $240{ }^{\circ} \mathrm{C}$ at a rate of $3.5^{\circ} \mathrm{C} / \mathrm{min}$ and then held at that temperature for an additional 10 minutes period. The detector and injection port temperatures were maintained at $250{ }^{\circ} \mathrm{C}$.

Injections of $1 \mu \mathrm{L}$ samples were made at a split ratio of 10:1. Fatty acids were identified by the comparison of their retention times with those of an authenticated laboratory standard (Supelco 37 Component FAME Mix). The fatty acid methyl ester standard mixture contained 19 derivatives including saturated, monounsaturated, and polyunsaturated fatty acids ranging in chain length from 4 to 24 carbon atoms. Fatty acid peak areas were quantified and expressed as percentage of total methyl ester area.

Cholesterol was determined by direct saponification of egg yolk followed by gas chromatography analysis (same equipment described above), according to the method developed by Botsoglou et al. (1998). Aliquots of $1 \mu \mathrm{L}$ from the saponified extracts were injected (split-less mode) in a fused silica capillary column ( $30 \mathrm{~m} \times 0.53 \mathrm{~mm}$ i.d.) coated with SPB-1 film thickness of $1.0 \mu \mathrm{m}$. The column temperature was programmed from 250 to $300{ }^{\circ} \mathrm{C}$ at $10^{\circ} \mathrm{C} / \mathrm{min}$ and held at $300^{\circ} \mathrm{C}$ for 15 minutes. Injection port and flame ionization detector temperatures were set at $300{ }^{\circ} \mathrm{C}$. Hydrogen carrier gas was set at $3.4 \mathrm{~mL} / \mathrm{min}$. 
All injections were made in a split less mode. Cholesterol was identified by comparing sample retention times to those of an authenticated laboratory standard. Quantification was carried against an external standard from a curve plotted with cholesterol levels and peak area values. Cholesterol concentrations were expressed as $\mathrm{mg} / 100 \mathrm{~g}$ yolk.

\subsection{Statistical analysis}

The results were submitted to analysis of variance using the procedure PROC ANOVA (STATISTICAL..., 2000). The data were submitted to regression analysis in order to determine the best level of the addition of cashew nut meal to the diet (5\% of probability).

\section{Results and discussion}

\subsection{Egg quality characteristics}

There were no significant differences $(\mathrm{p}>0.05)$ due to the addition of cashew nut meal (CNM) for the following quality characteristics: egg weight; egg yolk, albumen, and shell percentages; egg specific gravity; and Haugh Units (Table 3).

Results reported by Soares et al. (2007) for egg weight and egg yolk and albumen percentages in eggs of laying Japanese quails fed with different levels of CNM differed from those obtained in this study. These authors observed that the increase in CNM in the diets led a linear decrease in egg weight, whereas, the albumen percentage increased and yolk percentage decreased when the addition of CNM in the diet was up to $9 \%$. Therefore, the results obtained in the present study were promising since the egg quality characteristics were not adversely affected when the hens were fed diets containing CNM.

A linear decrease $(\mathrm{p}<0.05)$ in yolk color intensity was observed $\left(y=7.20-0.05 x ; R^{2}=0.73\right)$ with the addition of CNM
According to this equation, the addition of CNM reduced yolk pigmentation to 0.05 points in the color scale for each $1 \%$ of CNM addition (Table 3 ).

The yolk pigmentation reduction with the addition of CNM to laying hen diets is due to the reduction in carotenoid pigments in the diet since the CNM addition reduced the amount of maize present in the diet as shown in Table 1. Reduction in yolk pigmentation due to the addition of alternative ingredients in laying hen diets has been reported by some authors. Braga et al. (2005), studying the effect of coconut meal on laying hen diets, observed a reduction in yolk color with the addition of $5 \%$ of this alternative ingredient. Soares et al. (2007) also reported reduced yolk color with laying Japanese quails fed diets containing $20 \%$ CNM. These authors considered that the reduction in yolk pigmentation was probably due to the lower amount of maize in the CNM diets as compared to that in the control diet.

One of the most important quality parameters for buying retail eggs is yolk color since consumers associate this trait with nutritive value and vitamin content (GALOBART et al., 2004; ZHANG et al., 2011). Thus, according to this study, less than $15 \%$ of CNM should be added to laying hen diets; the use of higher levels require the addition of pigments to the layers feed. In order to prevent the problem of low pigment content in the egg yolk of laying hens fed diets containing coconut meal, Lima et al. (2007) added $0.025 \%$ of the natural pigment Sunred-50.

\subsection{Moisture, total solids and total lipids of the yolk}

Regression analysis showed no significant differences $(p>0.05)$ in moisture and total solids content of yolk with the addition of CNM (Table 4).

Barreto et al. (2006) also did not observed differences in yolk moisture and total solids content when hens were fed diets containing up to $20 \%$ of coconut meal. According to Ahn, Kim

Table 3. Egg quality analysis of eggs of laying hens fed diets containing different levels of cashew nut meal (CNM).

\begin{tabular}{|c|c|c|c|c|c|c|}
\hline \multirow{2}{*}{ Egg component } & \multicolumn{6}{|c|}{ Levels of CNM (\%) } \\
\hline & 0 & 5 & 10 & 15 & 20 & 25 \\
\hline Egg weight (g) & $63.10 \pm 1.82$ & $61.61 \pm 0.34$ & $62.31 \pm 2.23$ & $61.80 \pm 1.09$ & $60.98 \pm 1.44$ & $63.40 \pm 1.27$ \\
\hline Yolk percentage (\%) & $21.85 \pm 0.81$ & $22.35 \pm 0.41$ & $22.36 \pm 0.61$ & $22.40 \pm 0.48$ & $22.77 \pm 0.65$ & $22.38 \pm 0.77$ \\
\hline Albumen percentage (\%) & $68.30 \pm 0.86$ & $67.70 \pm 0.48$ & $67.59 \pm 0.53$ & $67.81 \pm 0.41$ & $67.80 \pm 0.74$ & $67.80 \pm 0.83$ \\
\hline Shell percentage (\%) & $9.85 \pm 0.23$ & $9.99 \pm 0.14$ & $10.05 \pm 0.28$ & $9.77 \pm 0.33$ & $9.47 \pm 0.38$ & $9.82 \pm 0.35$ \\
\hline Haugh unit & $85.19 \pm 2.56$ & $85.90 \pm 3.87$ & $82.87 \pm 2.40$ & $84.92 \pm 2.16$ & $86.43 \pm 3.93$ & $85.49 \pm 2.14$ \\
\hline Specific gravity & $1.090 \pm 0.00$ & $1.090 \pm 0.00$ & $1.091 \pm 0.00$ & $1.087 \pm 0.00$ & $1.087 \pm 0.01$ & $1.088 \pm 0.00$ \\
\hline Yolk color ${ }^{\mathrm{a}}$ & $6.99 \pm 0.30$ & $7.03 \pm 0.14$ & $6.59 \pm 0.33$ & $6.43 \pm 0.22$ & $6.26 \pm 0.25$ & $5.93 \pm 0.16$ \\
\hline
\end{tabular}

${ }^{a}$ Linear effect: $y=7.20-0.05 x ; R^{2}=0.73$, where $y=$ yolk color; $x=$ level of CNM inclusion; $R^{2}=$ determination coefficient. $n=5$.

Table 4. Composition of egg yolk of laying hens fed diets containing different levels of cashew nut meal (CNM).

\begin{tabular}{|c|c|c|c|c|c|c|}
\hline \multirow{2}{*}{ Components } & \multicolumn{6}{|c|}{ Levels of CNM (\%) } \\
\hline & 0 & 5 & 10 & 15 & 20 & 25 \\
\hline Moisture (\%) & $48.58 \pm 0.62$ & $48.91 \pm 0.41$ & $49.15 \pm 0.55$ & $49.12 \pm 0.70$ & $49.30 \pm 0.46$ & $48.93 \pm 0.32$ \\
\hline Solids (\%) & $51.37 \pm 0.66$ & $51.08 \pm 0.44$ & $50.83 \pm 0.59$ & $50.85 \pm 0.74$ & $50.60 \pm 0.54$ & $50.97 \pm 0.37$ \\
\hline Lipids $^{\mathrm{a}}(\%)$ & $20.55 \pm 0.23$ & $20.33 \pm 0.34$ & $20.43 \pm 0.33$ & $20.41 \pm 0.11$ & $20.67 \pm 0.18$ & $20.49 \pm 0.13$ \\
\hline
\end{tabular}


and Shu (1997), total solid levels of yolk increase with the age of birds. Additionally, the strain of the birds and the storage conditions of the eggs can change the relative proportion of the yolk components.

A linear increase $(\mathrm{p}<0.05)$ in yolk total lipid content was observed $\left(y=20.30+0.01 x ; R^{2}=0.17\right)$ with the addition of $\mathrm{CNM}$ in laying hen diets. According to this equation, for each $1 \%$ of CNM addition, there was an increase of $0.01 \%$ in total lipid content of the yolk (Table 4).

An increase in total lipids of yolk was also reported by Cherian et al. (2007), who observed an increase of 5.4\% with the addition of yellow grease (3.0\%) in the diet when compared to the yolk of hens fed rations containing yellow grease $(2.5 \%)+$ conjugated linoleic acid $(0.25 \%)$ and fish oil $(0.25 \%)$. According to Barreto et al. (2006), the yolk lipid content may be influenced by strain, egg size, and diet components, as well as by the type of fat in the diet. Total lipid content found in the yolks in this study is lower than that reported by Fennema (2000), who found values ranging from 32 to $35 \%$.

\subsection{Yolk fatty acid composition and cholesterol content}

The addition of CNM in laying hen diets led to a linear reduction $(\mathrm{p}<0.05)$ in palmitic acid $(\mathrm{C} 16: 0) \mathrm{y}=29.43-0.25 \mathrm{x}$; $\mathrm{R}^{2}=0.84$, stearic acid $(\mathrm{C} 18: 0) \mathrm{y}=14.82-0.02 \mathrm{x} ; \mathrm{R}^{2}=0.19$, linoleic $\operatorname{acid}(\mathrm{C} 18: 2 \mathrm{n} 6) \mathrm{y}=15.57-0.11 \mathrm{x} ; \mathrm{R}^{2}=0.41$, and docosahexaenoic (C22:6n3 - DHA) y $=1.67-0.03 x ; R^{2}=0.31$ (Table 5).

The reduction in palmitic acid content in yolk of layers fed diets containing $5 \%$ of $\mathrm{CNM}$ reflected the low proportion of this component in these diets, as can be seen in Table 2 .

Similar results were reported by Filardi et al. (2005) who observed lower palmitic acid content in yolks of hens fed diets containing canola oil compared to those fed diets containing cotton oil and lard. The level of this fatty acid in the yolk also reflected its proportion in the diet since the palmitic acid content was relatively low in the diet containing canola.

Palmitic acid is associated with the incidence of coronary heart disease due to the increase in serum total cholesterol and Low Density Lipoproteins (LDL) (PONNAMPALAM et al., 2011). Therefore, the palmitic acid reduction observed with $\mathrm{CNM}$ addition can be a nutritional advantage for consumers.
Moreover, the reduction in palmitic acid in the yolks due to CNM addition to hen diets was similar to that found in studies on canola oil, a high cost oil.

Unlike the fatty acid profile of the diets studied, the stearic acid content in yolk, showed lower levels in the yolks of layers fed the diet with the addition of 5\% CNM. The reduction of this component in the yolks could be due to the activity of the $\Delta-9$ desaturase enzyme which converts stearic acid into oleic acid during the lipid metabolism in hens (LATOUR et al., 1998).

Milinsk et al. (2003), investigating five different laying hens diets (four diets containing either canola, linseed, soybean or sunflower meals and oils and a control diet containing maize, soybean meal, and soybean oil), observed a decrease in palmitic and stearic acid contents in the eggs when compared to those of the control diet.

Oleicacid $(\mathrm{C} 18: \ln 9 \mathrm{c})$ content increased linearly $(\mathrm{p}<0.05)$ with CNM addition in laying hen diets $\left(y=28.35+0.22 x ; R^{2}=0.82\right)$. For palmitoleic (C16:1), $y=1.05+0.02 x-0.002 x^{2} ; R^{2}=0.87$ and arachidonic acids $(\mathrm{C} 20: 4 \mathrm{n} 6), \mathrm{y}=4.21+0.14 \mathrm{x}-0.004 \mathrm{x}^{2}$; $\mathrm{R}^{2}=0.43$, a quadratic effect $(\mathrm{p}<0.05)$ was observed with CNM addition. Therefore, palmitic and arachidonic acids increased with the addition of 5.00 and $17.50 \% \mathrm{CNM}$, respectively. The addition of higher CNM levels reduced the content these fatty acids (Table 5).

Palmitoleic acid was not detected in the experimental diets; however, reduced levels of this fatty acid was found in the yolks with the addition of CNM. Shang et al. (2004) also reported lower palmitoleic acid contents in the yolks of hens fed diets containing 1,2,3,4,5, and $6 \%$ conjugated linoleic acid compared to that of the control diet. The presence of palmitoleic acid in the yolks could be due to the activity of the $\Delta-9$ desaturase enzyme, which catalyzes the insertion of a double bond between C9 and C10 atoms of palmitic acid to form palmitoleic acid (AYDIN; COOK, 2004). Therefore, it can be concluded that the reduction in palmitoleic acid content in the eggs of hens fed with CNM diets reflected the palmitic acid content in the diets.

The high oleic acid concentration in the yolks of layers fed diets containing CNM supports the idea that the amount of fatty acid in the diet is directly responsible for its deposit in the yolk lipid fraction. The increase in the concentration of this

Table 5. Fatty acid composition of egg yolk of laying hens fed diets containing different levels of cashew nut meal (CNM).

\begin{tabular}{|c|c|c|c|c|c|c|}
\hline \multirow{2}{*}{ Fatty acid (\%) } & \multicolumn{6}{|c|}{ Levels of CNM (\%) } \\
\hline & 0 & 5 & 10 & 15 & 20 & 25 \\
\hline Palmitic $(\mathrm{C} 16: 0)^{\mathrm{a}}$ & $28.23 \pm 0.10$ & $28.99 \pm 0.96$ & $25.96 \pm 0.43$ & $25.19 \pm 0.42$ & $24.58 \pm 0.11$ & $23.31 \pm 0.47$ \\
\hline Stearic $(\mathrm{C} 18: 0)^{\mathrm{b}}$ & $15.73 \pm 0.35$ & $14.53 \pm 0.44$ & $14.94 \pm 0.19$ & $14.25 \pm 0.47$ & $14.25 \pm 0.27$ & $14.23 \pm 0.34$ \\
\hline Palmitoleic $(\mathrm{C} 16: 1)^{\mathrm{c}}$ & $1.00 \pm 0.01$ & $1.13 \pm 0.04$ & $1.03 \pm 0.08$ & $1.07 \pm 0.11$ & $0.76 \pm 0.06$ & $0.55 \pm 0.02$ \\
\hline Oleic $(\mathrm{C} 18: 1)^{\mathrm{d}}$ & $24.58 \pm 0.58$ & $28.58 \pm 0.46$ & $31.52 \pm 0.22$ & $31.93 \pm 0.58$ & $32.60 \pm 0.34$ & $33.49 \pm 0.23$ \\
\hline Linoleic $(\mathrm{C} 18: 2)^{\mathrm{e}}$ & $20.03 \pm 0.54$ & $16.13 \pm 0.20$ & $13.60 \pm 0.23$ & $12.84 \pm 0.40$ & $14.05 \pm 0.37$ & $13.24 \pm 0.13$ \\
\hline Arachidonic $(\mathrm{C} 20: 4)^{\mathrm{f}}$ & $5.16 \pm 0.32$ & $4.75 \pm 0.20$ & $5.26 \pm 0.19$ & $5.07 \pm 0.21$ & $5.31 \pm 0.21$ & $4.84 \pm 0.17$ \\
\hline Docosahexaenoic $(\mathrm{C} 22: 6)^{\mathrm{g}}$ & $2.24 \pm 0.12$ & $1.50 \pm 0.30$ & $1.24 \pm 0.08$ & $1.24 \pm 0.22$ & $1.51 \pm 0.28$ & $0.63 \pm 0.77$ \\
\hline
\end{tabular}


fatty acid can be a nutritional advantage for consumers due to its hypocholesterolemic effect (CASTRO et al., 2004).

These results are in agreement with those of Mazalli et al. (2004), who reported high oleic acid content in yolks of hens fed diets containing canola oil. These authors attributed this fact to the presence of canola oil. Similarly, since CNM is rich in oleic acid (60.32\%), it could lead to an increased deposition of this fatty acid in the yolk.

The reduction in yolk linoleic acid content with CNM addition observed in this study also reflected the proportion of this fatty acid in the diet. Grobas et al. (2001) also observed lower linoleic acid concentration in the yolk when hens were fed diets containing olive oil, which has low amount of linoleic acid when compared to that of sunflower or linseed oils. Moreover, the reduction in linoleic acid content in the yolks could also be related to its use in the biosynthesis of other fatty acids in the hen liver (WATKINS, 1991).

Arachidonic acid was not detected in layer diets. However, reduced content of this fatty acid was found in egg yolks with the addition of CNM. The presence of this fatty acid in the yolk could be due to the activity of the enzyme $\Delta-6$ desaturase that promotes the desaturation of linoleic acid into arachidonic acid (SIMOPOULOS, 2000).

Although docosahexaenoic acid was not detected in the diets either, this fatty acid was found in the yolks showing with reduced content due to the addition of CNM. Its presence in yolks could be due to the same enzyme, $\Delta-6$ desaturase, which also promotes the desaturation of $\alpha$-linolenic acid to form docosahexaenoic and eicosapentaenoic acids (DHA and EPA) (CARRILLO-DOMINGUEZ et al., 2005).

Thus, the reduction in DHA content in eggs of hens fed diets containing CNM reflected the a-linolenic acid content in the diets. Moreover, this reduction could be due the conversion of a-linolenic acid into DHA and EPA, which parallels that of linoleic acid into arachidonic acid. Both fatty acids compete for the same enzyme $\Delta 6$-desaturase in the first step of their respective conversions to form polyunsaturated 20-carbon derivatives (WATKINS, 1991).

These results are in agreement with those of Ahn et al. (1999), who reported lower linoleic, arachidonic, and docosahexaenoic acids contents in the yolks of hen fed diets containing 2.5 and $5.0 \%$ conjugated linoleic acid when compared to those of the control diet. The authors attributed these results to a low concentration of linoleic and a-linolenic acids in the diets containing conjugated linoleic acid. Similarly, the diets containing CNM produced egg yolks containing lower levels of linoleic, arachidonic, and docosahexaenoic acids when compared to those of the control diet.

Although a reduction in the polyunsaturated fatty acids (PUFA) content was observed, the addition of CNM led to a significant increase in the level of oleic acid, a monounsaturated fatty acid. This effect could be considered beneficial for consumers. According to Lima et al. (2000), high levels of monounsaturated fatty acids (MUFA) intake reduce the incidence of cardiovascular diseases. The authors associated these positive effects to the relative proportions of low density lipoprotein (LDL) and high density lipoprotein HDL-cholesterol in human plasma.

A reduction in saturated fatty acids (SFA) in the yolk due to changes in the diet was also observed by Milinsk et al. (2003), who found lower SFA yolk content when hens were fed diets containing canola meal and oil compared to that of the control diet. SFA are associated with the incidence of coronary heart diseases due to an increase in serum total cholesterol and a decrease in the level of low density lipoproteins (LDL) (SCHAEFER, 1997). Accordingly, the SFA reduction observed in the yolks of hens fed with CNM can be a nutritional advantage for consumers.

Regression analysis indicated that the addition of CNM in laying hen diets led to a linear increase $(p<0.05)$ in the monounsaturated fatty acid (MUFA) content, $y=29.69+0.19 x$; $\mathrm{R}^{2}=0.76$ and MUFA and saturated fatty (SFA) acids ratio (MUFA/SFA), $y=0.66+0.01 x ; R^{2}=0.88$. However, the SFA content was linearly reduced $(\mathrm{p}<0.05)$ with the addition of CNM to the diets $\left(y=44.26-0.28 x ; R^{2}=0.85\right)$ (Table 6).

With regard to the MUFA content, Grobas et al. (2001) also observed an increase in the level of these fatty acids in the yolks when hens were fed diets containing olive oil. The authors attributed this result especially to the oleic acid in the diet that was deposited in the eggs. It is important to emphasize that in the present study, the CNM consists in a low cost source of MUFA when compared to others such as canola and olive oil.

In humans, it has been reported that the ability of MUFA to lower blood cholesterol and the occurrence of coronary diseases are associated to the oxidation-stabilizing effect of MUFA on

Table 6. Total monounsaturated fatty acids (MUFA), total saturated fatty acids (SFA), MUFA/SFA ratio, and cholesterol content in yolk lipids of laying hens fed diets containing different levels of cashew nut meal (CNM).

\begin{tabular}{|c|c|c|c|c|c|c|}
\hline \multirow{2}{*}{ Lipids } & \multicolumn{6}{|c|}{ Levels of CNM (\%) } \\
\hline & 0 & 5 & 10 & 15 & 20 & 25 \\
\hline MUFA $^{\mathrm{a}}(\%)$ & $25.58 \pm 0.57$ & $29.71 \pm 0.49$ & $32.55 \pm 0.30$ & $33.00 \pm 0.63$ & $33.36 \pm 0.33$ & $34.04 \pm 0.22$ \\
\hline $\operatorname{SFA}^{\mathrm{b}}(\%)$ & $43.97 \pm 0.34$ & $43.52 \pm 1.33$ & $40.90 \pm 0.52$ & $39.44 \pm 0.39$ & $38.83 \pm 0.19$ & $37.54 \pm 0.61$ \\
\hline MUFA/SFA $^{c}$ & $0.58 \pm 0.01$ & $0.68 \pm 0.02$ & $0.79 \pm 0.01$ & $0.84 \pm 0.02$ & $0.86 \pm 0.01$ & $0.91 \pm 0.02$ \\
\hline Cholesterol $^{\mathrm{d}}(\mathrm{mg} / 100 \mathrm{~g})$ & $729.85 \pm 5.36$ & $727.75 \pm 4.35$ & $713.13 \pm 5.87$ & $680.00 \pm 6.73$ & $589.76 \pm 6.19$ & $571.98 \pm 5.14$ \\
\hline
\end{tabular}

$\mathrm{n}=5$; Mean \pm standard deviation; MUFA: $\Sigma$ (Palmitoleic + oleic); SFA: $\Sigma$ (Palmitic + stearic); ${ }^{a}$ Linear effect $\left(\mathrm{y}=29.69+0.19 \mathrm{x} ; \mathrm{R}^{2}=0.76, \mathrm{p}<0.05\right)$, where $\mathrm{y}=$ polyunsaturated fatty acid content; $\mathrm{x}=$ level of CNM addition; $\mathrm{R}^{2}=$ determination coefficient; ${ }^{\mathrm{b}}$ Linear effect $\left(\mathrm{y}=44.26-0.28 \mathrm{x} ; \mathrm{R}^{2}=0.85, \mathrm{p}<0.05\right) ;{ }^{\mathrm{c}} \mathrm{Linear}$ effect $\left(\mathrm{y}=0.66+0.01 \mathrm{x} ; \mathrm{R}^{2}=0.88, \mathrm{p}<0.05\right)$; ${ }^{\mathrm{d}} \mathrm{Linear}$ effect $\left(y=787.00-8.70 x ; R^{2}=0.92, p<0.05\right)$. 
the LDL. In addition, the highly oxidative stable nature of the intestinal mucosal cells has been reported to relate to its high oleic acid content (CHANDRASEKARA; SHAHIDI, 2011).

The quality of the fat eaten by the consumers can be related to the MUFA/SFA ratio, and foods with high MUFA/SFA ratios are considered appropriate for consumption. The increase in this ratio in the eggs analyzed in the present study, can therefore be considered as beneficial to consumers. Nam et al. (1997) reported a high MUFA/SFA ratio in the yolks of hens fed linseed diet when compared to diets containing animal fat. Thus, the results of lipid composition in this study show that the eggs of hens fed CNM diets are within the acceptable limits for a healthy human diet.

Yolk cholesterol content was also influenced $(\mathrm{p}<0.05)$ by the addition of CNM in layer feed, with a linear reduction adjusted to the equation $y=787.00-8.70 x ; R^{2}=0.92$ (Table 6).

The reduction in cholesterol content in yolks in diets containing CNM could be due to the increase in oleic acid content found in the diets since MUFA can lead to a reduction in cholesterol levels during bird lipid metabolism. Consumer concerns about the content of cholesterol of the human diet have grown due to the importance of cholesterol and cholesterol oxide products in the development of atherosclerosis (KIM et al., 2004). The results obtained in the present study suggest that the use of CNM in hen diets improve the nutritional value of the egg by reducing its cholesterol content.

Freitas et al. (2000) also reported a reduction in cholesterol content in the abdominal fat of broiler chickens fed diets containing CNM.

Although cholesterol content in eggs is naturally high, recent studies reported that the nutritional quality of fat in food products could be evaluated taking into account not only their cholesterol content, but also the levels of SFA, MUFA, and PUFA (MILINSK et al., 2003).

In general, the human body balances the cholesterol intake synthesizing this compound in the liver in smaller quantities, excreting it in a more efficient way, or absorbing it in lower proportions. Therefore, the amount of cholesterol ingested with food does not automatically raise blood cholesterol levels (BRANDÃO et al., 2005).

\section{Conclusions}

Based on the aforementioned observations and discussion, it can be concluded that egg quality characteristics and main yolk components (moisture and total solids) are not affected when hens are fed diets containing cashew nut meal. The addition of this ingredient in levels above 15\% result in yolks with lower pigmentation suggesting that the use of this ingredient in higher levels should be associated with some type of pigment supplementation. Moreover, the addition of the cashew nut meal in the diet increases the total lipid content of the yolks.

The results also show that yolk fatty acid composition can be favorably modified by the addition of cashew nut meal in the diet increasing the monounsaturated/saturated fatty acids ratio. Moreover, the use of cashew nut meal in the diet improves the nutritional value of egg by reducing its cholesterol content.

\section{Acknowledgments}

The authors gratefully acknowledge the financial support provided by Conselho Nacional de Desenvolvimento Científico e Tecnológico - CNPq.

\section{References}

AHN, D. U. et al. Effect of dietary conjugated linoleic acid on the quality characteristics of chicken eggs during refrigerated storage. Poultry Science, v. 78, n. 6, p. 922-928, 1999. PMid:10438141.

AHN, D. U.; KIM, S. M.; SHU, H. Effect of egg size and strain and age of hens on the solids content of chicken eggs. Poultry Science, v. 76, n. 6, p. 914-919, 1997. PMid:9181628.

ASSOCIATION OF OFFICIAL ANALYTICAL CHEMISTS - AOAC. Official methods of analysis. 15. ed. Association of Official Analytical Chemists, 1990. 1214 p.

AYDIN, R.; COOK, M. E. The effect of dietary conjugated linoleic acid on egg yolk fatty acids and hatchability in Japanese quail. Poultry Science, v. 83, n. 12, p. 2016-2022, 2004. PMid:15615015.

AYERZA, R.; COATES, W. Omega-3 enriched eggs: The influence of dietary a-linolenic acid fatty acid source on egg production and composition. Canadian Journal of Animal Science, v. 81, n. 3, p. 355-362, 2001. http://dx.doi.org/10.4141/A00-094

BARRETO, S. C. S. et al. Composição do ovo e dos ácidos graxos da gema de poedeiras comerciais alimentadas com rações contendo farelo de coco. Pesquisa Agropecuária Brasileira, v. 41, n. 12 , p. $1767-1773,2006$. http://dx.doi.org/10.1590/S0100204X2006001200011

BOTSOGLOU, N. A. et al. Yolk fatty acid composition and cholesterol content in response to level and form of dietary flaxseed. Journal Agricultural Food Chemistry, v. 46, n. 11, p. 4652-4656, 1998. http://dx.doi.org/10.1021/jf980586x

BRAGA, C. V. P. et al. Efeito da inclusão do farelo de coco em rações para poedeiras comerciais. Revista Brasileira de Zootecnia, v. 34 , n. 1, p. 76-80, 2005. http://dx.doi.org/10.1590/S151635982005000100010

BRANDÃO, P. A. et al. Ácidos graxos e colesterol na alimentação humana. Agropecuária Técnica, v. 26, n. 1, p. 5-14, 2005.

CARRILlO-DOMINGUEZ, S. et al. Cholesterol and n-3 and n- 6 fatty acid content in eggs from laying hens fed with red crab meal (Pleuroncodes planipes). Poultry Science, v. 84, n. 1, p. 167-172, 2005. PMid:15685957.

CASTRO, L. C. V. et al. Nutrição e doenças cardiovasculares: os marcadores de risco em adultos. Revista de Nutrição, v. 17, n. 3, p. 369-377, 2004. http://dx.doi.org/10.1590/S141552732004000300010

CHANDRASEKARA, K.; SHAHIDI, F. Effect roasting on phenolic content and antioxidant activities of whole cashew nuts, kernels, and testa. Journal of Agricultural and Food Chemistry, v. 59, n. 9, p. 5006-5014, 2011. PMid:21438525. http://dx.doi.org/10.1021/ jf2000772

CHERIAN, G. et al. Conjugated linoleic acid and fish oil in laying hen diets: effects on egg fatty acids, thiobarbituric acid reactive substances, and tocopherols during storage. Poultry Science, v. 86, n. 5, p. 953-958, 2007. PMid:17435031. 
EMBRAPA. Centro Nacional de Pesquisa de Suínos e Aves. Tabelas de composição química e valores energéticos de alimentos para suínos e aves. 3. ed. Concórdia: Embrapa-CNPSA, 1991. 97 p.

FENNEMA, O. R. Química de los alimentos. 2. ed. Zaragoza: Editorial Acribia, 2000. 1258 p.

FILARDI, R. S. et al. Influence of different fat sources on the performance, egg quality, and lipid profile of egg yolks of commercial layers in the second laying cycle. The Journal of Applied Poultry Research, v. 14, n. 2, p. 258-264, 2005.

FREITAS, E. R. et al. Farelo de castanha de caju em rações para frangos de corte. Pesquisa Agropecuária Brasileira, v. 41, n. 6, p. 10011006, 2006. http://dx.doi.org/10.1590/S0100-204X2006000600016

FREITAS, E. R. et al. Colesterol e ácidos graxos da gordura de frangos de corte alimentados com dietas contendo farelo da amêndoa da castanha de caju suplementado com enzimas. In: REUNIÃO ANUAL DA SOCIEDADE BRASILEIRA DE ZOOTECNIA, 37., 2000, Viçosa. Anais... Viçosa: SBZ, 2000. p.261.

FREITAS, E. R. et al. Comparação de métodos de determinação da gravidade específica de ovos e poedeiras comerciais. Pesquisa Agropecuária Brasileira, v. 39, n. 5, p. 509-512, 2004. http://dx.doi. org/10.1590/S0100-204X2004000500014

GALOBART, J. et al. Egg yolk color as affected by saponification of different natural pigmenting sources. The Journal of Applied Poultry Research, v. 13, n. 2, p. 328-334, 2004.

GROBAS, S. et al. Influence of source and percentage of fat added to diet on performance and fatty acid composition of egg yolks of two strains of laying hens. Poultry Science, v. 78, n. 8, p. 11711179, 2001.

KAMATH, V.; RAJINI, P. S. The efficiency of cashew-nut (Anacardium occidentale L.) skin extract as a free radical scavenger. Food Chemistry, v. 103, n. 2, p. 428-433, 2007. http://dx.doi.org/10.1016/j. foodchem.2006.07.031

KIM, J. H. et al. Oral administration of pravastatin reduces egg cholesterol but not plasma cholesterol in laying hens. Poultry Science, v. 83, n. 9, p. 1539-1543, 2004. PMid:15384905.

LATOUR, M. A. et al. Broiler breeder age and dietary fat influence the fatty acid profiles of fresh eggs and newly hatched chicks. Poultry Science, v. 77, n. 1, p. 47-53, 1998. PMid:9469750.

LIMA, F. E. L. et al. Ácidos graxos e doenças cardiovasculares: uma revisão. Revista da Nutrição, v. 13, n. 2, p. 73-80, 2000. http://dx.doi. org/10.1590/S1415-52732000000200001

LIMA, R. C. et al. Farelo de coco na ração de poedeiras comerciais: digestibilidade dos nutrientes, desempenho e qualidade dos ovos. Revista Brasileira de Zootecnia, v. 36, n. 5, p. 1340-1346, 2007. http://dx.doi.org/10.1590/S1516-35982007000600016

MAZALLI, M. R. et al. A comparison of the feeding value of different sources of fat for laying hens: 2. Lipid, cholesterol, and vitamin $\mathrm{E}$ profiles of egg yolk. The Journal of Applied Poultry Research, v. 13 , n. 2, p. $280-290,2004$.

MILINSK, M. C. et al. Fatty acid profile of egg yolk lipids from hens fed diets rich in n-3 fatty acids. Food Chemistry, v. 83, n. 2, p. 287-292, 2003. http://dx.doi.org/10.1016/S0308-8146(03)00094-3

NAM, K. et al. Influence of dietary supplementation with linseed and vitamin $\mathrm{E}$ on fatty acids, a-tocopherol and lipid peroxidation in muscles of broiler chicks. Animal Feed Science and Technology, v. 66 , n. $1-4$, p. $149-158,1997$. http://dx.doi.org/10.1016/S03778401(96)01108-X
NUNES, R. V. et al. Resultados de pesquisa em nutrição de aves no Brasil - resumo dos últimos 5 anos. Revista Brasileira de Ciência Avícola, v. 2, n. 2, p. 1-8, 2000. http://dx.doi.org/10.1590/S1516635X2000000200002

PONNAMPALAM, E. N. et al. Differential effects of natural palm oil, chemically - and enzymatically - modified palm oil on weight gain, blood lipid metabolites and fat deposition in a pediatric pig model. Nutrition Journal, v. 10, n. 1, p. 1-7, 2011. PMid:21586170 PMCid:3115846. http://dx.doi.org/10.1186/1475-2891-10-53

STATISTICAL ANALYSIS SYSTEM INSTITUTE - SAS. SAS/STAT: User's guide. version 6, 12. ed. Cary: SAS Institute Inc., 2000.

SCHAEFER, E. J. Effect of dietary fatty acids on lipoproteins and cardiovascular disease risk: summary. The American Journal of Clinical Nutrition, v. 65, n. 5, p. 1655-1656, 1997.

SHANG, X. G. et al. Effect of dietary conjugated linoleic acid on productivity of laying hens and egg quality during refrigerated storage. Poultry Science, v. 83, n. 10, p. 1688-1695, 2004. PMid:15510554.

SILVERSIDES, F. G.; BUDGELL, K. The relationships among measures of egg albumen height, $\mathrm{pH}$, and whipping volume. Poultry Science, v. 83, n. 10, p. 1619-1623, 2004. PMid:15510543.

SIMOPOULOS, A. P. Human requirement for $n-3$ polyunsaturated fatty acids. Poultry Science, v. 79, n. 7, p. 961-970, 2000. PMid:10901194.

SILVA, R. B. et al. Composição química e valores de energia metabolizável subprodutos agroindustriais determinados com diferentes aves. Acta Scientiarum Animal Science, v. 30, n. 3, p. $269-275,2008$.

SOARES, M. B. et al. Farelo de amêndoa da castanha de caju na alimentação de codornas japonesas na fase de postura. Revista Brasileira de Zootecnia, v. 36, n. 4, p. 1076-1082, 2007. http:// dx.doi.org/10.1590/S1516-35982007000500013

SZYMOZYK, B.; PISULEWSKI, P. M. Effects of dietary conjugated linoleic acid on fatty acid composition and cholesterol content of hen egg yolks. British Journal of Nutrition, v. 90, n. 1, p. 93-99, 2003. http://dx.doi.org/10.1079/BJN2003873

TREVISAN, M. T. S. et al. Characterization of alkyl phenols in cashew (Anacardium occidentale) products and assay of their antioxidant capacity. Food and Chemical Toxicology, v. 44, n. 2, p. 188-197, 2006. PMid:16095792. http://dx.doi.org/10.1016/j. fct.2005.06.012

TROX, J. et al. Bioactive compounds in cashew nut (Anacardium occidentale L.) kernels: Effect of different shelling methods. Journal of Agricultural and Food Chemistry, v. 58, n. 9, p. 53415346, 2010. PMid:20387832. http://dx.doi.org/10.1021/jf904580k

VENKATACHALAM, M.; SATHE, S. K. Chemical composition of selected edible nut seeds. Journal of Agricultural and Food Chemistry, v. 54, n. 13, p. 4705-4714, 2006. PMid:16787018. http:// dx.doi.org/10.1021/jf0606959

WANG, Y. et al. Fatty acid determination in chicken egg yolk: a comparison of different methods. Poultry Science, v. 79, n. 8, p. 1168-1171, 2000. PMid:10947186.

WATKINS, B. A. Importance of essential fatty acids and their derivatives in poultry. Journal Nutrition, v. 121, n. 9, p. 1475-1485, 1991. PMid:1880625.

ZHANG, W. et al. Influence of canthaxanthin on broiler breeder reproduction, chick quality, and performance. Poultry Science, v. 90 , n. 7, p. 1516-1522, 2011. PMid:21673167. http://dx.doi. org/10.3382/ps.2010-01126 